\title{
Single block costal cartilage graft in rhinoplasty
}

\section{Enxerto de cartilagem costal em monobloco na rinoplastia}

\author{
Daniel Dias Lopes ${ }^{1}$ \\ Bruno Gazire de Araújo \\ ANDRADE $^{1}$ \\ Michel Luciano Holger \\ Toledano Vaena ${ }^{2}$ \\ Denise Salles Coelho da \\ MотA $^{3}$
}

Study conducted at Hospital Federal de Bonsucesso, Rio de Janeiro, RJ, Brazil.

Submitted to SGP (Sistema de Gestão de Publicações/Manager Publications System) of RBCP (Revista Brasileira de Cirurgia Plástica/Brazilian Journal of Plastic Surgery).

Received: May 9, 2011 Accepted: July 12, 2011

\begin{abstract}
Introduction: It is often necessary to use inclusion materials in rhinoplasty for nose restructuring. The costal cartilage graft is one of the inclusion material options, and its use is indicated when septal cartilage is not available or is not sufficient to provide necessary remodeling of the nose. Methods: Four patients who, for diverse reasons, had saddle nose or poor projection of the nasal dorsum underwent rhinoplasty. All received a costal cartilage graft carved in an " $L$ " shape. The long branch of the "L" was used to reconstruct the dorsum and the short branch was used to support the new dorsum and the columella, repositioning the nasal tip. Results: All patients had a good postoperative evolution and had no significant complications. There was a clear reconstruction of the dorsum and harmonization of the nasal tip. The results were as expected and were long-lasting. Conclusions: The use of a costal cartilage graft carved in a single block in rhinoplasty provides enhancement of the nasal dorsum and tip projection, promoting appropriate nasal remodeling.
\end{abstract}

Keywords: Rhinoplasty. Nose/surgery. Cartilage. Reconstructive surgical procedures.

\section{RESUMO}

Introdução: Na rinoplastia frequentemente é necessário o uso de materiais de inclusão para que se obtenha a reestruturação nasal. O enxerto de cartilagem costal é uma das opções e tem seu uso indicado quando a cartilagem septal não está disponível ou não é suficiente para promover o necessário remodelamento nasal. Método: Quatro pacientes que, por motivos diversos, apresentavam nariz em sela ou dorso nasal pouco projetado foram submetidos a rinoplastia. Todos receberam enxerto de cartilagem costal esculpido em formato de " $L$ ". O ramo longo do "L" teve como objetivo reconstituir o dorso e o ramo curto, dar suporte ao novo dorso e à columela, reposicionando a ponta nasal. Resultados: Todos os pacientes evoluíram bem no pós-operatório e não apresentaram complicação significativa. Houve nítida reconstituição do dorso e harmonização da ponta do nariz. Os resultados mostraram-se previsíveis e duradouros. Conclusões: O emprego de enxerto de cartilagem costal esculpido em monobloco na rinoplastia proporciona ganho de projeção do dorso e da ponta nasais, promovendo adequado remodelamento nasal.

Descritores: Rinoplastia. Nariz/cirurgia. Cartilagem. Procedimentos cirúrgicos reconstrutivos.

1. Aspiring member of the Brazilian Society of Plastic Surgery (SBCP), resident physician of the Plastic Surgery Service at Hospital Federal Bonsucesso, Rio de Janeiro, RJ, Brazil.

2. Full member of the Brazilian Society of Plastic Surgery (SBCP), medical residency preceptor of the Plastic Surgery Service at Hospital Federal Bonsucesso, Rio de Janeiro, RJ, Brazil.

3. Full member of the Brazilian Society of Plastic Surgery (SBCP), head of the Plastic Surgery Service at Hospital Federal Bonsucesso, Rio de Janeiro, RJ, Brazil. 


\section{INTRODUCTION}

Augmentation rhinoplasty, for both repair and aesthetic reasons, frequently requires the use of materials that can provide an increase in support or volume. Several types of materials have been tested for this purpose and can be divided into two groups: grafts and implants. Grafts, according to their origin, can be autologous or allogeneic. Autogenous grafts are derived from the patient, such as cartilage, bone, fascia, and dermis. Allogeneic grafts are obtained from donors of the same species and are most commonly represented by irradiated cartilage and acellular dermis ${ }^{1}$. Implants are biocompatible synthetic substances that include silicone, polytetrafluoroethylene $e^{1,2}$, and polymethylmethacrylate.

The use of each of these materials has advantages and disadvantages arising from their inherent characteristics. Moreover, it is necessary to take into account the particular requirements of each patient in order to choose the best option. However, most authors favor autogenous grafting ${ }^{3-6}$ since it has high biocompatibility and low risk of infection and extrusion.

Among autogenous grafts, cartilage has a prominent position because of its physical properties and because it is easy to obtain. In most cases, the nasal septum cartilage is considered the best option ${ }^{7,8}$. Use of costal cartilage is indicated when the septal cartilage is not available or is not sufficient to promote the necessary projection and structuring of the nasal dorsum and tip ${ }^{5}$.

This study, carried out at Hospital Federal de Bonsucesso (Rio de Janeiro, RJ), demonstrated the use of a costal cartilage graft carved in a single piece (single block) in rhinoplasty. This choice was based on the qualities of this material as well as the characteristics of the patients in this study.

\section{METHODS}

The cases selected were of four patients who underwent surgery between October 2008 and August 2009 and required rhinoplasty for various reasons. These patients all had a clear requirement of restructuring and projection of the nasal dorsum and tip: three patients for restorative purposes and one patient for aesthetic purposes.

Patients who required reconstructive surgery were systematically assessed. A clinical history was taken, followed by the etiological definition of each case. Physical examination showed the presence of saddle nose in all patients, and computed tomography confirmed deficiency of the nasal septum as the sole or main cause of the nasal dorsum and tip (Figure 1). The case of aesthetic surgery was a patient with a typical Negroid nose.

All patients had the same requirement of large graft amounts for correct nose remodeling, and costal cartilage

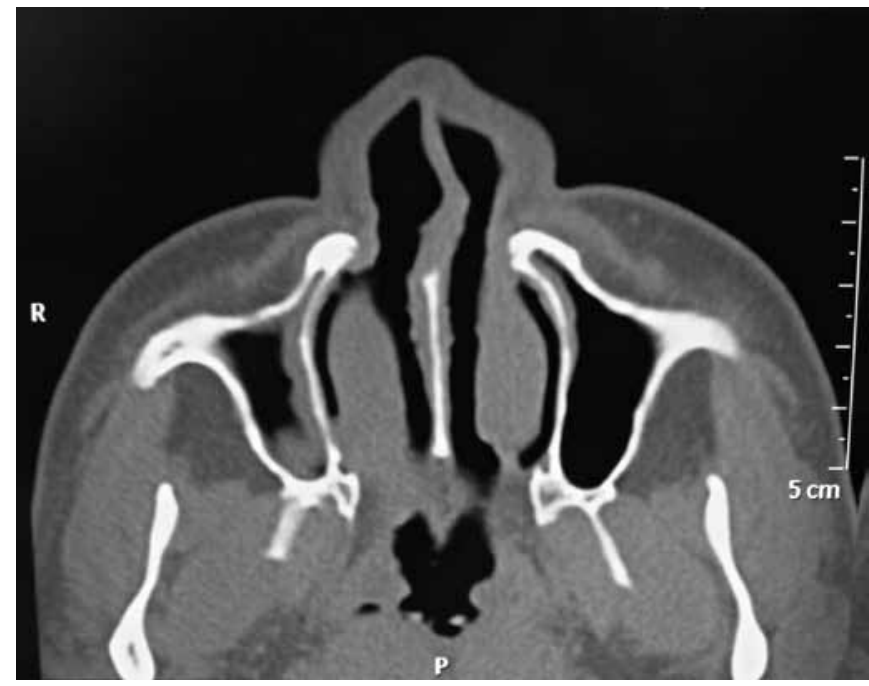

Figure 1-Computed tomography of case 1, demonstrating the absence of septal cartilage and consequent collapse of the nasal dorsum.

was chosen as the donor source. Moreover, cartilage graft of a suitable size was selected so that after carving, it would have an "L" shape in a single piece. The longer branch was used to reconstruct the dorsum, whereas the short branch was used to support the new dorsum and the columella and to project the nasal tip.

All patients were assessed through preoperative tests and a pre-anesthetic consultation. After the proposed surgery was thoroughly explained to the patients, they (or their legal guardians) signed the informed consent form.

The patients were placed under general anesthesia, and the surgical procedures were performed in three sequential stages: exploration of the nasal defect, procurement of the costal cartilage graft, and nasal reconstruction. The surgical particularities of each patient will be described separately. However, because the costal cartilage graft was procured in a standardized manner, the surgical technique described below applies to all patients.

\section{Surgical Technique}

The surgical technique was conducted as follows:

- skin marking with a dermographic pen on the synchondrosis projection area formed by the sixth, seventh, and eighth ribs (marking the inframammary groove in women);

- skin and subcutaneous incision up to the identification and exposure of the costal perichondrium;

- incision and detachment of the perichondrium;

- marking of the cartilage to be excised from the referred synchondrosis (at the time of exploring the nasal defect, a mold of sterile paper was prepared so that it would 
replicate the " $L$ " shape with the appropriate measures of the graft);

- incision and removal of the graft;

- leakage test with forceps and air distention under pulmonary hyperinsufflation for detection of possible pneumothorax;

- homeostasis revision;

- closing of the perichondrium;

- suturing of the surgical wound in layers.

The obtained graft was placed on a bench and carved with a scalpel using the paper mold (Figure 2). The peripheral limits of the graft were symmetrically cut off to preserve its central area at the end of the handling procedure. Thus, the principles of Gibson \& Davis ${ }^{9}$ were respected. After carving, the graft was placed in saline for a minimum of 15 to 30 minutes so that any early deformities could be detected $^{5}$

\section{Patients}

The first patient was a 36-year-old man diagnosed with Hansen's disease in 1988. After undergoing treatment, he was considered cured in 1994. Saddle nose developed due to impairment of the septal cartilage caused by the disease. In October 2008, he underwent an exo-rhinoplasty in which a subperiosteal tunnel was created over the nasal bones where the graft's longer branch was inserted. The graft's lower branch was placed between the soft parts in the columellar region that usually contains the medial branches of the alar cartilages. The graft was fixed to the nasal bones with steel wire in a superior position only.

The second patient was a 20 -year-old woman injured in an accident in October 2008, which resulted in a

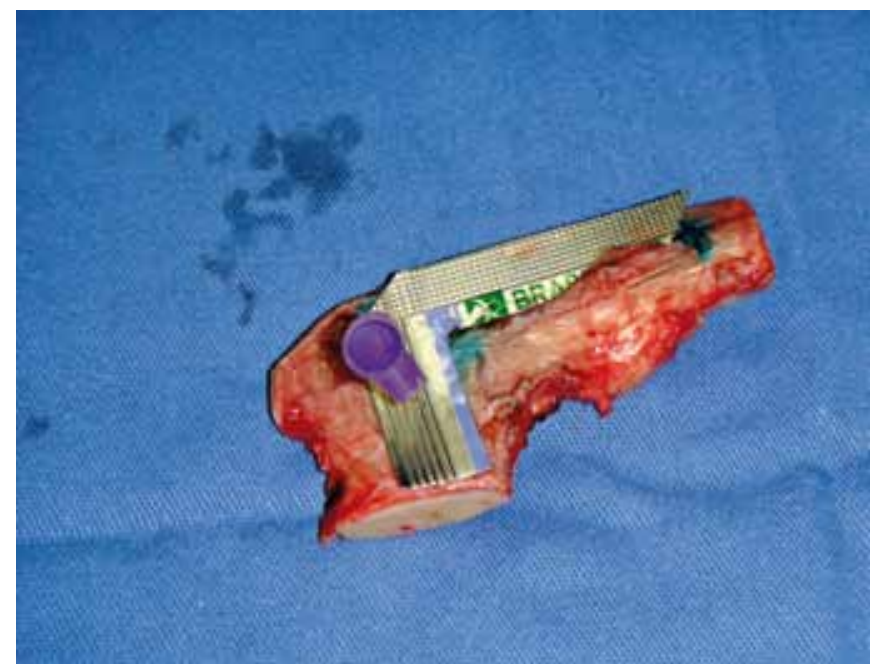

Figure 2 - Costal cartilage before being carved under the mold that determined the size and shape to be obtained. nasal-orbital-ethmoidal fracture. At that time, she had been treated by an oral and maxillofacial surgery team, which accessed the nasal bone dorsum by coronal incision and reduced it with the aid of a titanium membrane and screws. The nasal bone dorsum was reapproached in May 2009 due to the persistence of a saddle nose. The titanium materials used in the first surgery were removed through the coronal access. An exo-rhinoplasty was also performed for placement of costal cartilage graft, which was fixed with steel wire to the frontal bone and to the anterior nasal spine. Finally, the graft was covered with a pericranium flap.

The third patient was a 38-year-old man with a Negroidtype nasal conformation and complaints of an aesthetic nature. He wished to undergo rhinoplasty to increase the nasal dorsum and tip projection. He underwent surgery in July 2009. A tunnel for graft placement was created using exo-rhinoplasty; in this case, the graft was not fixed using synthetic material because it was well inserted in the receptor site. Next, a small vertical incision was made in the glabellar region for placing small fragments of the cartilage graft in order to smooth the transition of the upper end of the graft in the "L" with the glabella. The procedure was completed with nasal alar rotation.

The last patient, a 15-year-old girl, had ethmoidal sinusitis with septal abscess when she was five years old. This resulted in resorption of the septal cartilage and collapse of the nasal dorsum. She underwent surgery in August 2009 and an exorhinoplasty was performed, creating a tunnel for inserting the cartilage graft. The graft was fixed to the nasal bones in a superior position using a Kirschner wire.

\section{RESULTS}

All surgeries proceeded as planned, and there were no complications. Pneumothorax, which may occur upon removal of the costal graft, did not occur in the assessed cases.

The patients had a trouble-free immediate postoperative period and remained hospitalized for a maximum period of two days after surgery. They used standard antibiotic prophylaxis and analgesia with anti-inflammatory drugs and opioid derivatives.

No complications, such as hematoma, seroma, infection, or dehiscence of surgical wound, occurred at either the donor site or at the receptor site of the graft. The thoracic region was more sensitive to pain but responded well to analgesics.

Edema, inherent in any surgery, was significantly present in the nose and its surroundings. However, as expected, it gradually receded over the days and weeks following surgery. Chest wall deformities did not occur in the early or late postoperative period, and no patient had any respiratory complaints after the first few postoperative days. 
Currently, the average length of patient follow-up is 21.5 months, ranging from 18 months (case 4 ) to 28 months (case 1). Throughout this time, the surgery results were monitored, and the positive results obtained in the immediate postoperative period have been retained in all patients. The grafts have maintained their volume, resistance, and stability and showed no signs of deformity or resorption.

The preoperative and late postoperative period photographs for each patient (Figures 3 to 18) show evidence of projection enhancement of the nasal dorsum and tip in addition to improvement of the nasolabial angle. Patients reported satisfaction with the aesthetic results and had no complaints.

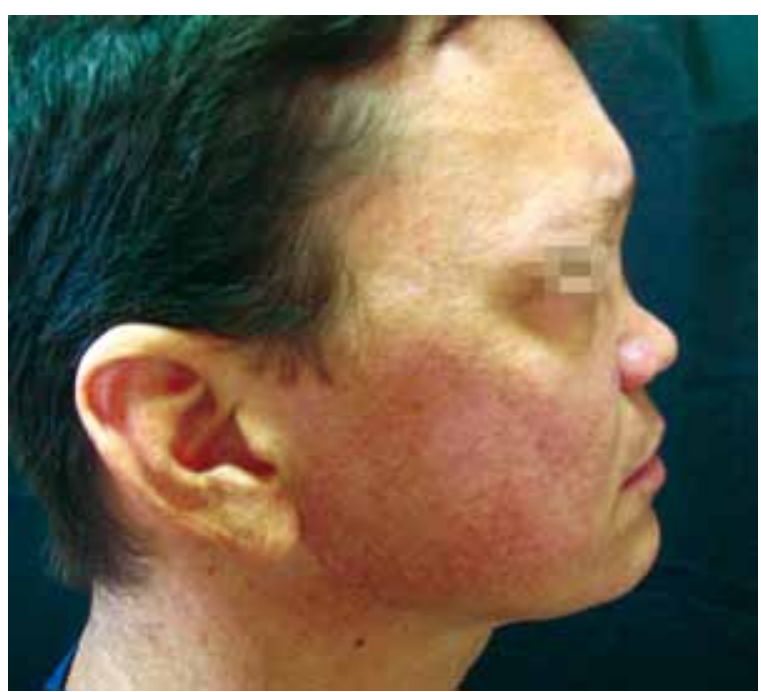

Figure 3 - Case 1. Preoperative period: lateral view.

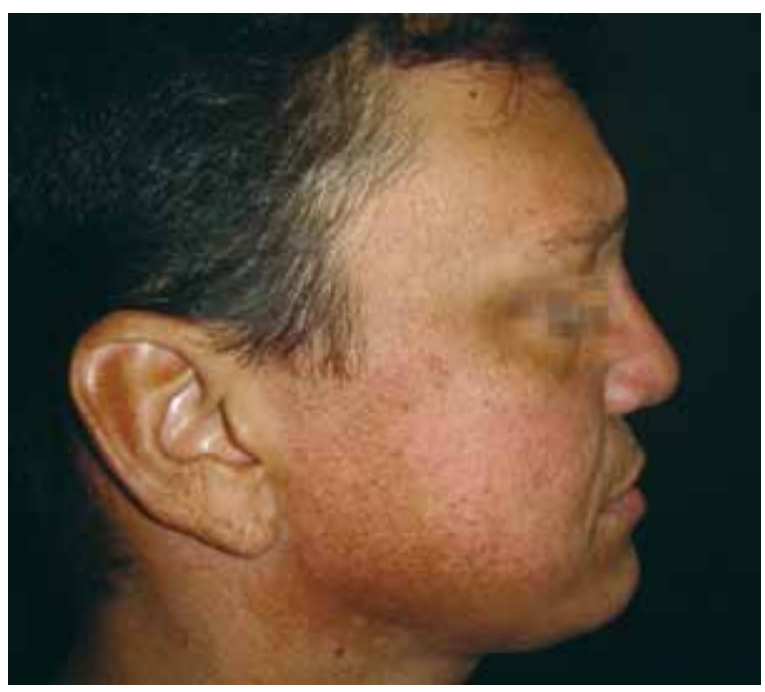

Figure 4 - Case 1. Postoperative period: lateral view.

\section{DISCUSSION}

In rhinoplasty, several types of materials can be used to provide nasal projection and support.

Use of alloplastic implants is a more practical alternative because the morbidity inherent to procurement of autogenous material and manipulation of allogeneic tissue is avoided. However, alloplastic implants are

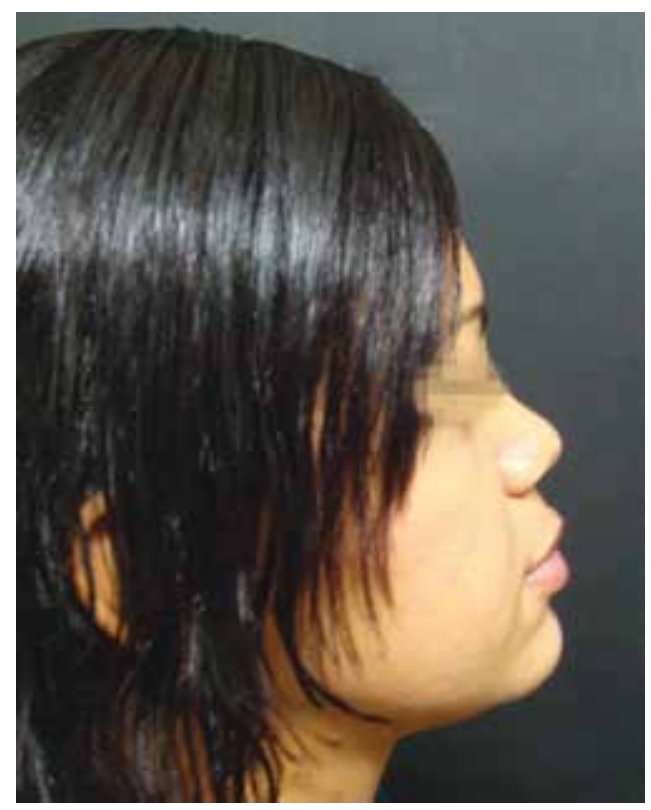

Figure 5 - Case 2. Preoperative period: lateral view.

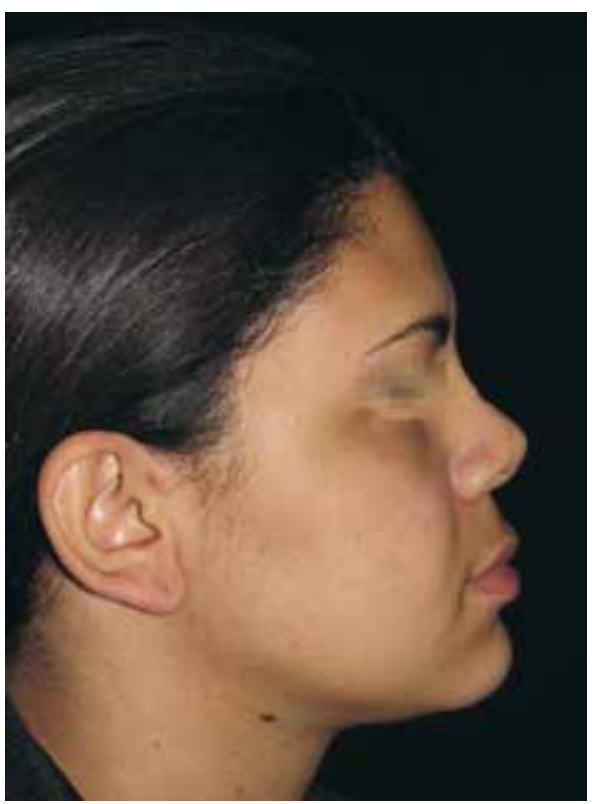

Figure 6-Case 2. Postoperative period: lateral view. 


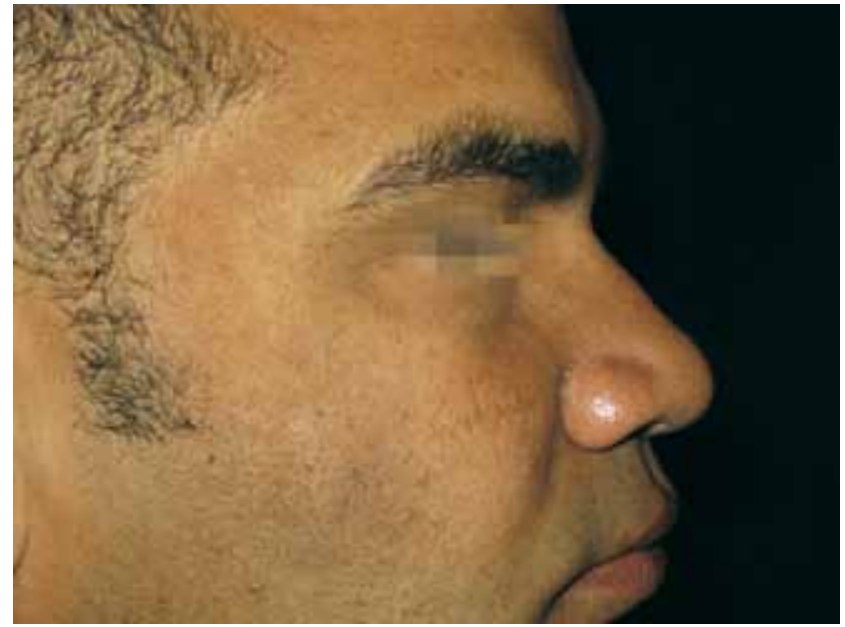

Figure 7-Case 3. Preoperative period: lateral view.

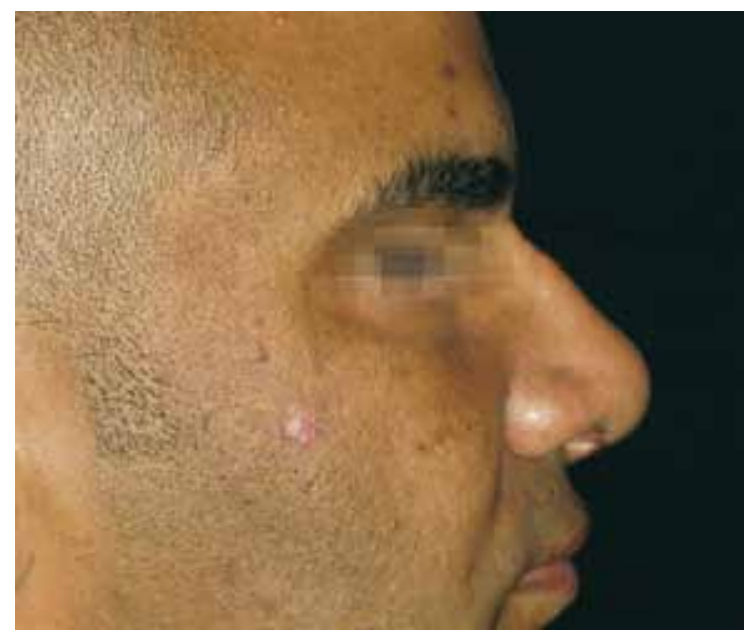

Figure 8-Case 3. Postoperative period: lateral view.

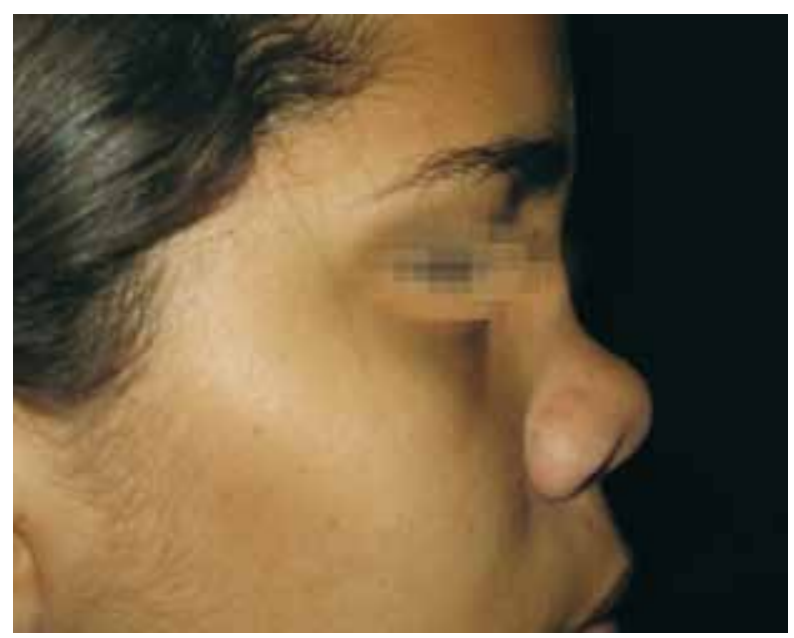

Figure 9-Case 4. Preoperative period: lateral view.

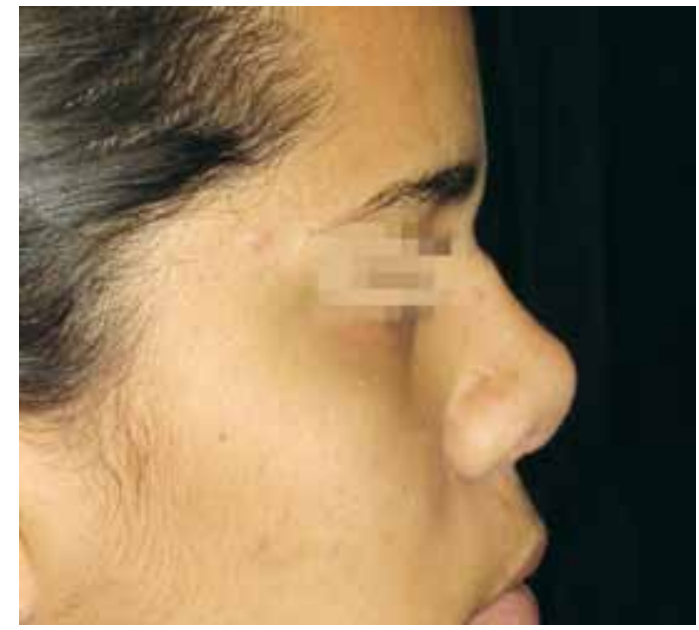

Figure 10 -Case 4. Postoperative period: lateral view

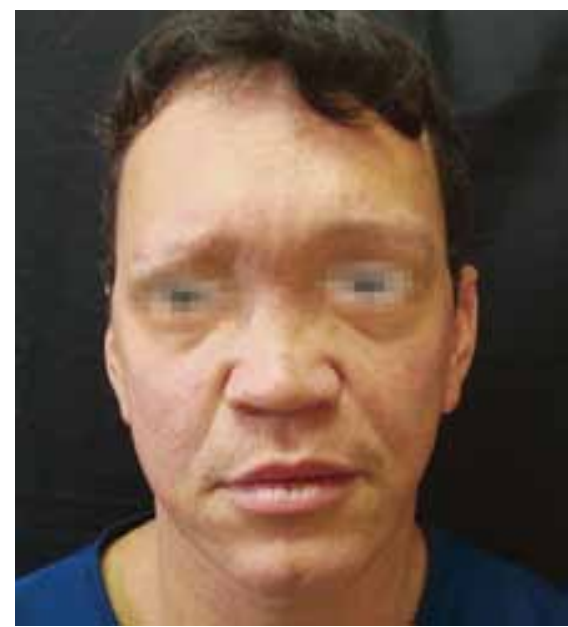

Figure 11 - Case 1. Preoperative period: frontal view.

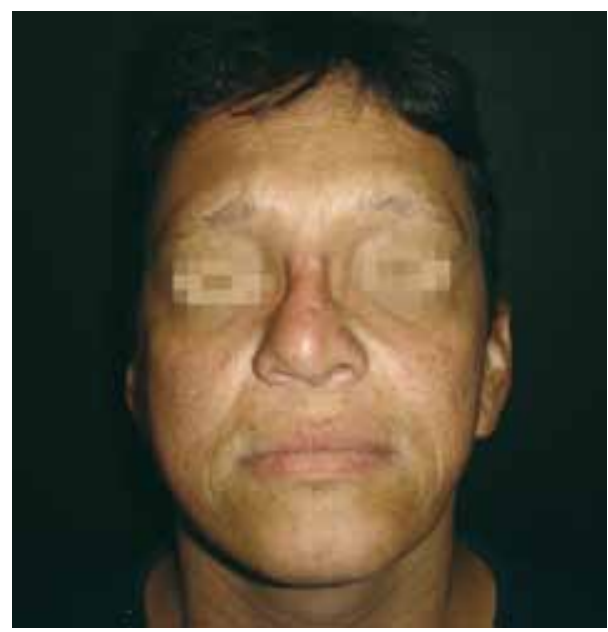

Figure 12 -Case 1. Postoperative period: frontal view. 
most susceptible to complications such as infection or extrusion ${ }^{2,10-12}$.

Although allografts also enable nasal correction without the need for additional surgical intervention to obtain an autograft, many technical details complicate the use of allografts. For example, it is necessary to rule out the presence of infectious diseases in the donor source. Another obstacle is the construction and maintenance of a tissue bank, which invariably increases treatment costs. Moreover, although Kridel et al. ${ }^{13}$ recently advocated the use of irradiated allogeneic cartilage, most authors emphasize that the biggest problem is allograft resorption in the long term.

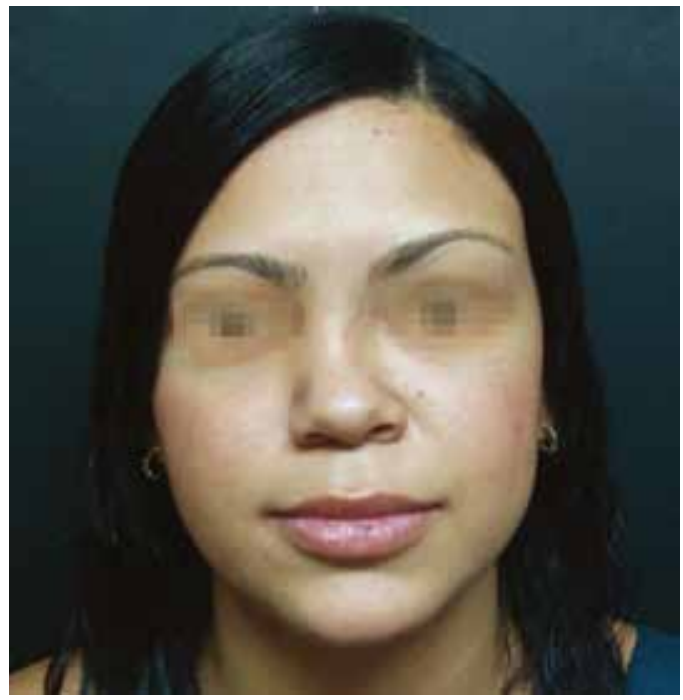

Figure 13 - Case 2. Preoperative period: frontal view.

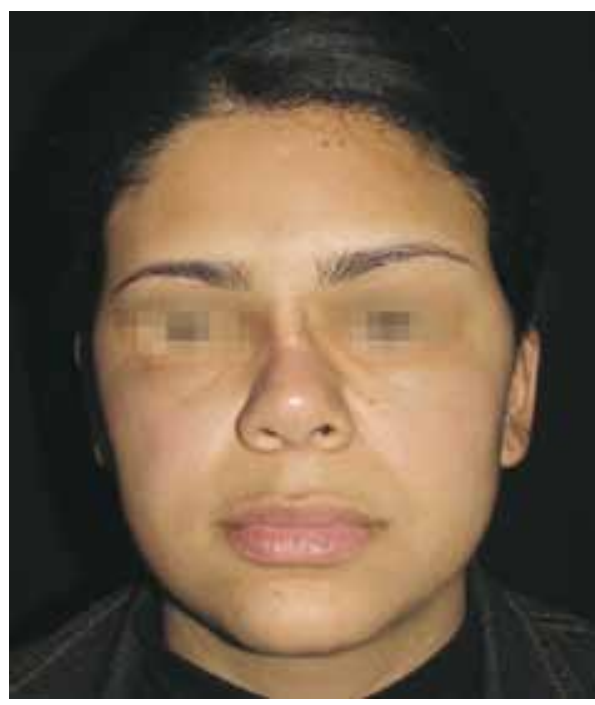

Figure 14 - Case 2. Postoperative period: frontal view.
In view of previously reported results, there is a clear preference for autogenous grafts because of their higher biocompatibility. Among the tissue options available for autografting, the following are highlighted: nasal septum cartilage, ear cartilage, costal cartilage, and skull bone ${ }^{1}$.

Bone graft is an alternative to the use of cartilage. The skull has been the preferred donor site of bone because of its resistance and lower rate of resorption ${ }^{14}$. However, it is difficult to carve this bone. Moreover, the skull is very hard, in contrast to the cartilaginous structures of the natural nose.

The septal cartilage is usually the best option because it is easily carved and is obtained at the same surgical site of rhinoplasty. It has good physical strength and low rates of resorption, infection, and deformity. However, its use is limited in cases where the septum has significant deviations or when a large amount of cartilage grafting is required ${ }^{7}$.

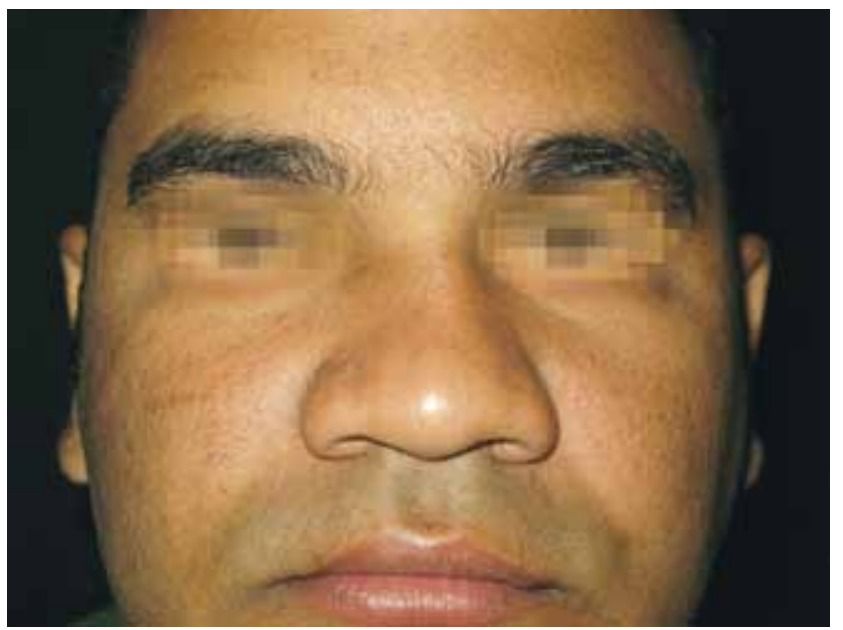

Figure 15 -Case 3. Preoperative period: frontal view.

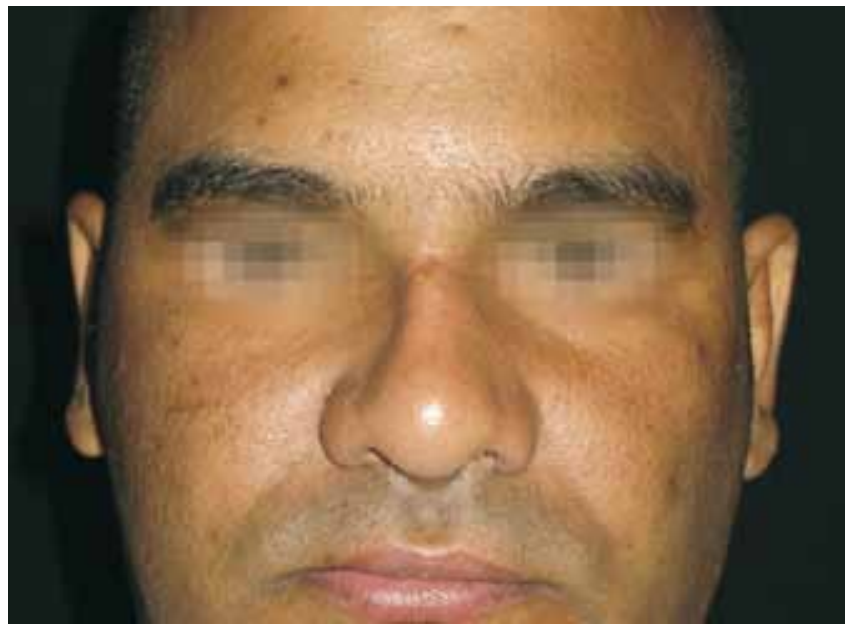

Figure 16-Case 3. Postoperative period: frontal view. 
This is applicable when the cause of the nasal defect is not septum deficiency.

The ear cartilage is preferred in situations where structural support is not necessary and the use of septal cartilage is not viable $^{15}$. The conformation of ear cartilage is more suitable for repair of lateral nasal cartilage and of the external nasal valve $^{16}$.

The use of costal cartilage is indicated when the septal cartilage is insufficient or poor ${ }^{5}$, as in the cases presented in this paper. Costal cartilage is present in abundant quantities and, similar to septal cartilage, has a low absorption rate ${ }^{17}$ and is carved without difficulty. However, this approach involves the inconvenience of donor area morbidity, which may include pain, infection, dehiscence, and even chest wall deformity and iatrogenic pneumothorax. Nevertheless, such complications can be avoided by the suitable selection of

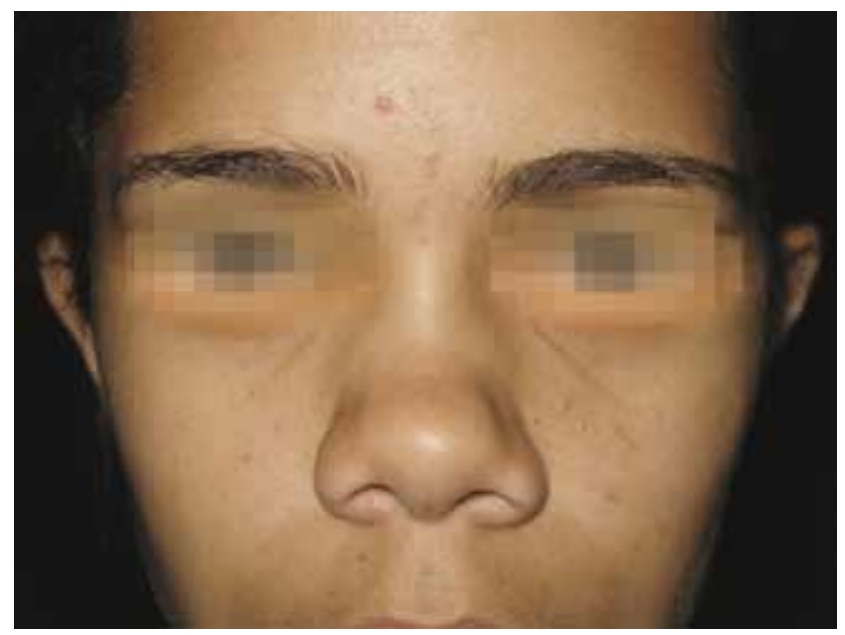

Figure 17 - Case 4. Preoperative period: frontal view.

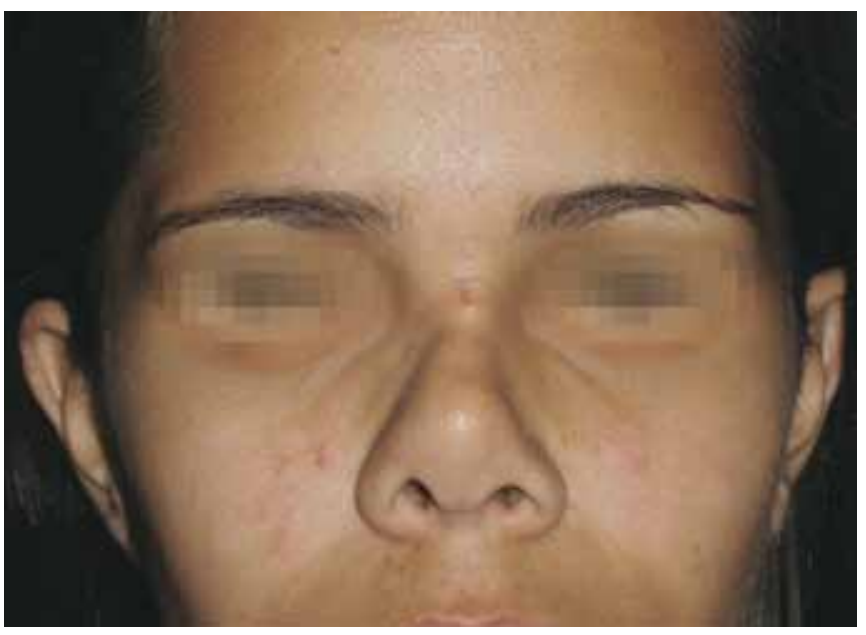

Figure 18 - Case 4. Postoperative period: frontal view. patients and meticulous observation of technique ${ }^{5}$, as has been demonstrated.

The costal cartilage graft was obtained in a single "L"-shaped block, thus avoiding secondary procedures to join cartilage segments. A single seamless piece has a higher resistance and is less subject to mechanical stresses. These characteristics are of fundamental importance since the graft has a support function. In addition, a single block graft undergoes less resorption than two smaller pieces grafted separately.

During the 1990s, internal stabilization of a costal cartilage graft with Kirschner wire was proposed in order to avoid possible deformation in the graft over time ${ }^{18}$; however, this technique was not used. The strict observation of Gibson \& Davis ${ }^{9}$ principles was chosen with the same purpose, i.e., the graft was carved in order to maintain the balance of its internal forces, providing stability to its new form. The maintenance of good results in the reported cases demonstrates that this technique is effective and reproducible.

Authors such as Mutaf ${ }^{19}$ obtain the graft from a single rib and carve it in order to reproduce the lost structure of nose cartilage. Such techniques are more complex and therefore more susceptible to complications.

The use of a single-block autogenous cartilage graft was chosen for augmentation rhinoplasty to combine qualities such as integration, support, strength, durability, and simplicity. The achievement of good results confirms these principles.

\section{CONCLUSIONS}

In rhinoplasty, the use of a costal cartilage graft carved in a single block provides an enhancement of the nasal dorsum and tip projection, promoting appropriate nasal remodeling.

\section{REFERENCES}

1. Sajjadian A, Rubinstein R, Naghshineh N. Current status of grafts and implants in rhinoplasty: part I. Autologous grafts. Plast Reconstr Surg. 2010;125(2):40e-9e.

2. Dini GM. Correções de deformidades nasais com o uso de cartilagem costal. (Nasal deformities corrections using costal cartilage) In: Ferreira LM, eds. Cirurgia plástica. Barueri: Manole; 2007. p. 355-60.

3. Sherris DA. Graft choices in aesthetic and reconstructive rhinoplasty. In: Proceedings of $16^{\text {th }}$ Congress in Otorhinolaryngology. Bologna, Italy: Monduzzi; 1997. p. 157-61.

4. Sherris DA. Caudal and dorsal septal reconstruction: an algorithm for graft choices. Am J Rhinol. 1997;11(6):457-66.

5. Sherris DA, Kern EB. The versatile autogenous rib graft in septorhinoplast. Am J Rhinol. 1998;12(3):221-7.

6. Khurana D, Sherris DA. Grafting material for augmentation septorhinoplasty. Curr Opin Otolaryngol Head Neck Surg. 1999;7:210-3.

7. Gunter JP, Rohrich RJ. Augmentation rhinoplasty: dorsal onlay grafting using shaped autogenous septal cartilage. Plast Reconstr Surg. 1990;86(1):39-45. 
8. Ortiz-Monasterio F, Olmedo A, Oscoy LO. The use of cartilage grafts in primary aesthetic rhinoplasty. Plast Reconstr Surg. 1981;67(5):597-605.

9. Gibson T, Davis WB. The distortion of autogenous cartilage grafts: its cause and prevention. Br J Plast Surg. 1958;10:257-74.

10. Gunter JP. Aumento do dorso: cartilagem costal autóloga. (Dorsum increase: autologous costal cartilage) In: Gunter JP, Rohrich RJ, Adams WP Jr, eds. Dallas rinoplastia: cirurgia do nariz pelos mestres. (Dallas rhinoplasty: nose surgery by the masters) Rio de Janeiro: Revinter; 2006. p. 344-52.

11. Hiraga Y. Complications of augmentation rhinoplasty in the Japanese. Ann Plast Surg. 1980;4(6):495-9.

12. Davis $P K$, Jones SM. The complications of silastic implants. Experience with 137 consecutive cases. Br J Plast Surg. 1971;24(4):405-11.

13. Kridel RW, Ashoori F, Liu ES, Hart CG. Long-term use and follow-up of irradiated homologous costal cartilage grafts in the nose. Arch Facial Plast Surg. 2009;11(6):378-94.
14. Tessier P. Autogenous bone grafts taken from the calvarium for facial and cranial applications. Clin Plast Surg. 1982;9(4):531-8.

15. Brent B. The versatile cartilage autograft: current trends in clinical transplantation. Clin Plast Surg. 1979;6(2):163-80.

16. Donald PJ. Cartilage grafting in facial reconstruction with special consideration of irradiated grafts. Laryngoscope. 1986;96(7):786807.

17. Tardy ME Jr, Denneny J $3^{\text {rd }}$, Fritsch MH. The versatile cartilage autograft in reconstruction of the nose and face. Laryngoscope. 1985;95(5):523-33.

18. Gunter JP, Clark CP, Friedman RM. Internal stabilization of autogenous rib cartilage grafts in rhinoplasty: a barrier to cartilage warping. Plast Reconstr Surg. 1997;100(1):161-9.

19. Mutaf M. The anatomic replication technique (ART): a new approach in saddle nose correction. Ann Plast Surg. 2008;61(2):169-77.

\section{Correspondence to:}

Daniel Dias Lopes

Rua Voluntários da Pátria, 86 - ap. 202 - Botafogo - Rio de Janeiro, RJ, Brazil - CEP 22270-010

E-mail: danielguaranesia@hotmail.com 